Brit. J. industr. Med., 1955, 12, 60.

\title{
THE TOXICITY OF OZONE IN THE PRESENCE OF OXIDES OF NITROGEN
}

\author{
BY \\ W. M. DIGGLE and J. C. GAGE \\ From the Imperial Chemical Industries Ltd., Industrial Hygiene Research Laboratories, Welwyn, Herts
}

(RECEIVED FOR PUBLICATION NOVEMBER 15, 1954)

In a previous paper we (Diggle and Gage, 1954) have referred to published statements that the toxicity of ozone is increased if oxides of nitrogen are present and we have suggested the hypothesis that if, in fact, this is so, then the increased toxicity is likely to be due to the presence of nitrogen pentoxide, to which the lower oxides of nitrogen are converted by ozone. As a first step to establish this, we undertook a study of the toxicity of nitrogen pentoxide and we demonstrated that it is a "lung irritant " gas of high potency.

Since the appearance of our paper, a careful review of the literature on the toxicity of ozone has been made by Stokinger (1954) from which it is evident that although there is general agreement that ozone produces pulmonary oedema and emphysema, there are wide variations in the concentrations which are regarded as necessary to produce these symptoms. A direct comparison of the results of various investigators is rendered difficult by the use of different experimental conditions and species, by different degrees of purity of the ozone, and by deficient or faulty analytical control of the test atmospheres.

In the investigation described in the present paper, we have measured the toxicity of ozone to rats and the effect thereon of the presence of added amounts of nitrogen dioxide, and we have studied the extent to which this can be attributed to the analytically determined amounts of nitrogen pentoxide present. We have also made analytical measurements on an industrial atmosphere where conditions are favourable for the production of ozone together with oxides of nitrogen.

\section{Preparation of Test Atmospheres}

Ozone generated by means of a silent discharge ozonizer (Tack Air Conditioning Ltd., Model LO3). Oxygen $(99.5 \%)$ was passed from a cylinder through the ozonizer at a rate of 1 to $3 \mathrm{l} . / \mathrm{min}$. ; at this rate the ozone output was of the order of $27 \mathrm{mg}$. $/ \mathrm{min}$. The ozonized oxygen was allowed to leak at controlled rates in the region of $20 \mathrm{ml}$./min. into a stream of filtered air which had been dried by means of a silica gel column to a humidity of about $10 \%$. Analytical control of the ozone dilution demonstrated that provided the flow rates were maintained constant, the ozone concentration of the atmosphere produced remained constant for the duration of each experiment. The ozone dilution passed through a 5-1. mixing vessel and thence to the exposure chamber. The exposure chamber was constructed, as described in our previous paper, from a 20.1. glass desiccator; the inlet and outlet tubes were sealed into the chamber by means of polythene bungs and all flexible connexions in the system were made with polyvinyl chloride tubing.

The nitrogen dioxide-ozone mixtures were prepared by adding nitrogen dioxide to the air used to dilute the ozonized oxygen. Pure nitrogen dioxide, prepared as previously described, was passed into a flask cooled to $-80^{\circ} \mathrm{C}$. in a solid carbon dioxide-acetone freezing mixture. A proportion of the air stream, according to the concentration required, was diverted through this flask, entering it by a jet situated within $1 \mathrm{~cm}$. of the surface of the solid nitrogen dioxide maintained at $-80^{\circ} \mathrm{C}$. Analytical control demonstrated that the atmospheric concentrations so produced were reasonably constant.

\section{Analytical Methods}

Ozone.-After a critical review of methods of determining ozone in air, Wilska (1951) has selected the iodometric method of Gluckauf, Heal, Martin, and Paneth (1944) who recommended absorbing the gas in a potassium iodide solution buffered to $p \mathrm{H} 7$. This procedure has been followed in the present investigation ; air was sampled at intervals from the outlet of the exposure chamber at $4 \mathrm{1} / \mathrm{min}$. through an absorber (Gage, 1952) containing $10 \mathrm{ml}$. buffered potassium iodide solution. The contents of the absorber were washed into a titration flask with $25 \mathrm{ml}$. water and titrated with $0.01 \mathrm{~N}$ sodium thiosulphate. By means of control experiments with two absorbers in series it has been shown that one absorber completely removes all the ozone from the air sample. This method is stated not to be subject to interference from low concentrations of nitrogen dioxide, but it is alleged that at 100 p.p.m. nitrogen dioxide gives a significant reaction. 
Ozone and Nitrogen Dioxide.-The nitrogen dioxide concentration in the test atmosphere was determined at the sampling point on the air exit tube of the exposure chamber. The method used was that of Patty and Petty (1943) ; these authors state that ozone may interfere by oxidation of the nitrite produced to nitrate, but it is evident from the balance sheet between the concentrations of ozone, nitrogen dioxide, and nitrogen pentoxide, which are given in Table 3 and discussed below, that if such an interference exists it cannot be regarded as serious. The initial concentration of nitrogen dioxide fed into the air stream was determined by analysing the air before the ozone supply was connected. From the difference between these two results the amount of nitrogen dioxide reacting with ozone was determined.

Where the nitrogen dioxide content of the mixture was of the order of 10 p.p.m. or less, the ozone concentration was measured during exposure as described above. At the end of the experiment the nitrogen dioxide feed was stopped, and, after an appropriate period for flushing out the apparatus, the ozone concentration was again measured. The difference between these two values gave the amount of ozone reacting with the nitrogen dioxide.

When the nitrogen dioxide concentration was much in excess of 10 p.p.m. it interfered with the direct estimation of the ozone concentration during exposure and the values in Table 4 enclosed in brackets have been obtained by subtracting from the measured initial ozone concentration an amount equivalent to one-half the measured decrease in nitrogen dioxide, expressed in p.p.m. This procedure assumes that the decrease in ozone concentration is due to the reaction of 1 molecule of ozone with 2 of nitrogen dioxide; an inspection of those experiments in Table 3 where both the ozone and nitrogen dioxide losses have been measured suggests that the procedure is inferior to a direct determination of ozone concentration, but that it is not likely to introduce errors which will invalidate any of the conclusions.

The analytical techniques used give their answer in terms of $\mathrm{mg} . / \mathrm{m}^{3}$ air. In this paper the usual calculation has been applied to convert these figures into parts per million by volume (p.p.m.), a procedure which is open to theoretical objection but which permits the reaction of ozone and nitrogen dioxide on a molar basis to be readily apparent.

Nitrogen Pentoxide.-The nitrogen pentoxide content of the test atmospheres was determined by the direct nitration of a 2:4 xylenol reagent (Diggle and Gage, 1954). We have found that a nitrogen dioxide atmosphere, prepared as described above, does not, in the absence of ozone, react at all with this reagent. In our previous paper we made the observation that a nitrogen dioxide atmosphere, prepared by the volatilization of a chloroform solution of the substance, is absorbed to a small extent under these conditions; the conclusion must be drawn that nitrogen dioxide can exist in molecular association with chloroform, sufficiently loosely not to interfere with the determination of the substance by the static absorption in Griess-Ilosvay reagent, but, nevertheless, in a manner which permits the partial retention of the vapour in the xylenol reagent.

\section{Toxicity of Ozone}

Single Exposures.-Table 1 shows the effect of a single four-hour exposure of a range of concentrations of ozone on rats and Table 2 is a summary of similar experiments on mice.

TABLE 1

EFFECT ON RATS OF SINGLE FOUR-HOUR EXPOSURE TO OZONE

\begin{tabular}{|c|c|c|c|c|}
\hline \multirow{2}{*}{$\begin{array}{l}\text { Concen- } \\
\text { tration } \\
\text { (p.p.m.) }\end{array}$} & \multicolumn{3}{|c|}{ Rats } & \multirow[b]{2}{*}{ Effects } \\
\hline & No. & Sex & $\begin{array}{l}\text { Mean } \\
\text { Weight } \\
\text { (g.) }\end{array}$ & \\
\hline $3 \cdot 4$ & 3 & $\mathbf{F}$ & 150 & $\begin{array}{l}\text { Laboured breathing towards end of } \\
\text { exposure, complete recovery }\end{array}$ \\
\hline $3 \cdot 6$ & 4 & $\mathbf{M}$ & 202 & As above \\
\hline 8.0 . & 4 & $\mathbf{M}$ & 182 & $\begin{array}{l}\text { Dyspnoea after } 2 \text { hours, becoming } \\
\text { severe } ; 1 \text { death within } 24 \text { hours } \\
\text { of exposure }\end{array}$ \\
\hline 9.0 & 3 & F & 160 & $\begin{array}{l}\text { Dyspnoea after } 2 \text { hours, becoming } \\
\text { severe ; no deaths }\end{array}$ \\
\hline $14 \cdot 0$ & 3 & F & 160 & $\begin{array}{l}\text { Dyspnoea and lethargy after } 30 \\
\text { minutes; all died during exposure }\end{array}$ \\
\hline $17 \cdot 0$ & 4 & $\mathbf{M}$ & 195 & $\begin{array}{l}\text { Acute dyspnoea after } 2 \text { hours ; } 3 \text { died } \\
\text { during exposure, } 1 \text { later }\end{array}$ \\
\hline $30-36$ & 4 & $\mathbf{M}$ & 188 & $\begin{array}{l}\text { Acute dyspnoea after } 2 \text { hours; all } \\
\text { died during exposure }\end{array}$ \\
\hline
\end{tabular}

TABLE 2

EFFECT ON MICE OF SINGLE FOUR-HOUR EXPOSURE TO OZONE

\begin{tabular}{|c|c|c|c|c|}
\hline \multirow{2}{*}{$\begin{array}{l}\text { Concen- } \\
\text { tration } \\
\text { (p.p.m.) }\end{array}$} & \multicolumn{3}{|c|}{ Mice } & \multirow[b]{2}{*}{ Effects } \\
\hline & No. & Sex & $\begin{array}{c}\text { Mean } \\
\text { Weight } \\
\text { (g.) }\end{array}$ & \\
\hline 9 & 6 & $\mathbf{F}$ & 20 & $\begin{array}{l}\text { Dyspnoea developed during expo- } \\
\text { sure, severe in } 3 \text { mice which died } \\
\text { within } 24 \text { hours of exposure }\end{array}$ \\
\hline $12 \cdot 7$ & 5 & $\mathrm{~F}$ & 20 & $\begin{array}{l}\text { Dyspnoea rapidly became severe, } 2 \\
\text { died during exposure, remainder } \\
\text { died within } 24 \text { hours }\end{array}$ \\
\hline $16 \cdot 5$ & 7 & $\mathbf{F}$ & 20 & $\begin{array}{l}\text { As above, } 3 \text { died during exposure, } \\
\text { remainder within } 24 \text { hours }\end{array}$ \\
\hline 24 & 5 & $\mathbf{F}$ & 20 & As above, all died during exposure \\
\hline
\end{tabular}

The effect of the gas on both species is similar; the results do not permit a statistical calculation of a lethal concentration (L.C. 50), but it is most probably in the region of 10 to 12 p.p.m. Concentrations below this may produce signs of transient respiratory distress during the experiment, above this figure the animals become comatose and develop acute dyspnoea which terminates in death during or within 24 hours after the exposure.

Post-mortem examination revealed the lungs distended with oedematous fluid. Histological examination of pulmonary tissue showed extensive 
oedema and emphysema, but no haemorrhage or engorgement of alveolar capillaries.

Repeated Exposures.- Six male rats (120 to $140 \mathrm{~g}$.) were exposed to $2 \cdot 5$ p.p.m. ozone for four hours a day for eight days. They suffered no apparent discomfort and gained weight normally. Lungs removed from these animals after death appeared normal and histological examination revealed nothing abnormal.

The experiment was repeated on five male rats ( 160 to 250 g.) with a 4.5 p.p.m. ozone concentration for 19 days. All of the animals save one survived the experiment and increased in weight normally, though they showed slight respiratory distress towards the end of each four-hour exposure period from which they recovered overnight. During the fifth exposure one of the rats $(160 \mathrm{~g}$.) developed dyspnoea which became increasingly severe with successive exposures. It lost weight and died after the twelfth exposure.

On post-mortem examination the lungs of the rats which survived the 4.5 p.p.m. ozone exposures appeared normal, though one showed small oedematous patches on histological examination. In the rat which succumbed during the exposure, the thorax was distended and the lungs very enlarged; two lobes appeared haemorrhagic. On histological examination of the lungs of this animal, there were, in addition to oedema and emphysema, localized areas of sero-fibrinous haemorrhagic exudate, enmeshing large numbers of leucocytes.

TABLE 3

REACTION OF OZONE AND NITROGEN DIOXIDE TO PRODUCE NITROGEN PENTOXIDE

\begin{tabular}{|c|c|c|c|c|c|c|c|c|}
\hline \multicolumn{2}{|c|}{$\begin{array}{c}\text { Ozone } \\
\text { (p.p.m.) }\end{array}$} & \multicolumn{2}{|c|}{$\begin{array}{c}\mathrm{NO}_{2} \\
\text { (p.p.m.) }\end{array}$} & \multicolumn{3}{|c|}{$\begin{array}{c}\mathrm{N}_{2} \mathrm{O}_{\mathrm{s}} \\
\text { (p.p.m.) }\end{array}$} & \multicolumn{2}{|c|}{$\begin{array}{l}\% \mathrm{~N}_{2} \mathrm{O}_{6} \\
\text { Found } \\
\end{array}$} \\
\hline $\begin{array}{c}\text { Before } \\
\text { Mix- } \\
\text { ing }\end{array}$ & $\begin{array}{c}\text { After } \\
\text { Mix- } \\
\text { ing }\end{array}$ & $\begin{array}{c}\text { Before } \\
\text { Mix- } \\
\text { ing }\end{array}$ & $\begin{array}{l}\text { After } \\
\text { Mix- } \\
\text { ing }\end{array}$ & $\begin{array}{l}\text { Calcu- } \\
\text { lated } \\
\text { from } \\
\mathrm{O}_{3} \\
\text { Loss }\end{array}$ & $\begin{array}{l}\text { Calcu- } \\
\text { lated } \\
\text { from } \\
\mathrm{NO}_{2} \\
\text { Loss }\end{array}$ & $\begin{array}{l}\text { Mea- } \\
\text { sured }\end{array}$ & $\begin{array}{c}\text { On } \\
\text { Ozone } \\
\text { Loss }\end{array}$ & $\begin{array}{l}\text { On } \\
\text { NO, } \\
\text { Loss }\end{array}$ \\
\hline 5.6 & 5.9 & 5.0 & 1.8 & 0 & 1.9 & 0 & - & - \\
\hline $5 \cdot 2$ & 5.0 & $9 \cdot 8$ & 4.75 & 0.2 & 2.5 & 0.31 & 155 & $12 \cdot 4$ \\
\hline 11.5 & 10.7 & 4.75 & $2 \cdot 1$ & 0.8 & 1.3 & 0.31 & 38.8 & 23.8 \\
\hline 9.9 & 8.9 & $4 \cdot 1$ & 2.9 & 1.0 & 0 & 0.44 & 44.0 & $73 \cdot 3$ \\
\hline $9 \cdot 2$ & 8 & $11 \cdot 1$ & 5 & 1.2 & & & $70 \cdot 0$ & $31 \cdot 1$ \\
\hline 10.8 & $9 \cdot 1$ & $4 \cdot 2$ & $2 \cdot 2$ & 1.7 & 1.0 & 0.88 & $51 \cdot 8$ & 88.0 \\
\hline 11.9 & $9 \cdot 2$ & $9 \cdot 7$ & 3.9 & $2 \cdot 7$ & 3.0 & 0.94 & $34 \cdot 8$ & $31 \cdot 4$ \\
\hline 9.0 & 5.6 & 10.4 & 3.9 & 3.4 & $3 \cdot 2$ & 1.4 & $41 \cdot 2$ & 43.8 \\
\hline $10 \cdot 2$ & - & $20 \cdot 4$ & 12.5 & - & $7 \cdot 0$ & 1.9 & - & $27 \cdot 1$ \\
\hline $6 \cdot 7$ & - & $22 \cdot 2$ & $11 \cdot 5$ & - & $5 \cdot 3$ & 2.94 & - & $55 \cdot 5$ \\
\hline $6 \cdot 5$ & - & 40.0 & $27 \cdot 0$ & - & 6.5 & 3.38 & - & 52.0 \\
\hline $7 \cdot 6$ & - & $33 \cdot 4$ & $21 \cdot 6$ & - & 5.9 & $3 \cdot 38$ & - & $57 \cdot 2$ \\
\hline
\end{tabular}

TABLE 4

EFFECT ON RATS (200-250 g.) OF SINGLE FOUR-HOUR EXPOSURE TO MIXTURES OF OZONE AND NITROGEN DIOXIDE

\begin{tabular}{|c|c|c|c|c|c|c|}
\hline \multirow{2}{*}{$\begin{array}{l}\text { Ozone } \\
\text { (p.p.m.) }\end{array}$} & \multirow{2}{*}{$\underset{\text { (p.p.m.) }}{\mathrm{NO}_{2}}$} & \multirow{2}{*}{$\begin{array}{l}\mathrm{N}_{2} \mathrm{O}_{5} \\
\text { (p.p.m.) }\end{array}$} & \multirow{2}{*}{$\begin{array}{c}\text { Total } \\
\text { Equivalent } \\
\text { Ozone } \\
\text { Concentra- } \\
\text { tion } \\
\text { (p.p.m.) } \\
\end{array}$} & \multicolumn{2}{|c|}{ Rats } & \multirow{2}{*}{ Effects } \\
\hline & & & & Sex & No. & \\
\hline $5 \cdot 9$ & $1 \cdot 8$ & 0 & 5.9 & $\mathbf{M}$ & 3 & Slight dyspnoea, no deaths \\
\hline $5 \cdot 0$ & $4 \cdot 75$ & $0 \cdot 31$ & $5 \cdot 9$ & $\mathbf{M}$ & 3 & Slight dyspnoea, no deaths, lungs normal \\
\hline 56 & 3.9 & $1 \cdot 4$ & $9 \cdot 8$ & $\mathbf{M}$ & 3 & Dyspnoea, lethargy, no deaths \\
\hline$(1 \cdot 3)$ & $11 \cdot 5$ & 2.94 & $10 \cdot 1$ & $\mathbf{F}$ & 3 & $\begin{array}{l}\text { Lethargy, dyspnoea becoming acute in } 1 \text { rat which died within } \\
24 \text { hours with intense oedema and emphysema }\end{array}$ \\
\hline (0) & $27 \cdot 0$ & $3 \cdot 38$ & $10 \cdot 1$ & $\mathbf{M}$ & 3 & $\begin{array}{l}\text { Dyspnoea and lethargy, no deaths but patches of oedema and } \\
\text { emphysema in lungs }\end{array}$ \\
\hline $8 \cdot 9$ & $2 \cdot 9$ & 0.44 & $10 \cdot 2$ & $\mathbf{F}$ & 3 & As above \\
\hline $8 \cdot 0$ & $5 \cdot 75$ & 0.84 & $10 \cdot 5$ & $\mathbf{F}$ & 3 & $\begin{array}{l}\text { Severe dyspnoea, all died within } 24 \text { hours with extensive } \\
\text { oedema and emphysema }\end{array}$ \\
\hline$(1 \cdot 25)$ & $21 \cdot 6$ & $3 \cdot 38$ & $11 \cdot 4$ & $\mathbf{F}$ & 3 & $\begin{array}{l}\text { Dyspnoea and lethargy, no deaths, patches of oedema and } \\
\text { emphysema in lungs }\end{array}$ \\
\hline $10 \cdot 7$ & $2 \cdot 1$ & $0 \cdot 31$ & $11 \cdot 6$ & $\mathbf{F}$ & 3 & As above \\
\hline$(6 \cdot 0)$ & $12 \cdot 5$ & 1.9 & $11 \cdot 7$ & $\mathbf{F}$ & 3 & $\begin{array}{l}\text { Dyspnoea, one died within } 24 \text { hours, lung oedema and } \\
\text { emphysema }\end{array}$ \\
\hline $9 \cdot 1$ & $2 \cdot 2$ & 0.88 & $11 \cdot 7$ & $\mathbf{M}$ & 3 & $\begin{array}{l}\text { Dyspnoea, } 1 \text { died during exposure, } 1 \text { within } 24 \text { hours ; lung } \\
\text { oedema }\end{array}$ \\
\hline $9 \cdot 2$ & $3 \cdot 9$ & 0.94 & $12 \cdot 0$ & $\mathbf{M}$ & 3 & $\begin{array}{l}\text { Acute dyspnoea, all died within } 24 \text { hours ; extensive oedema } \\
\text { and emphysema in lungs }\end{array}$ \\
\hline
\end{tabular}




\section{Ozone and Nitrogen Dioxide}

Production of Nitrogen Pentoxide.-Table 3 is a summary of the analytical results on a series of atmospheres containing ozone and nitrogen dioxide.

From the decrease in the concentrations of ozone and nitrogen dioxide, which results from the admixture and which have been calculated as described in a previous section, are derived the expected nitrogen pentoxide concentrations, according to the equation $2 \mathrm{NO}_{2}+\mathrm{O}_{3}=\mathrm{N}_{2} \mathrm{O}_{5}+\mathrm{O}_{2}$. These concentrations calculated from the ozone and nitrogen dioxide losses are in fairly good agreement with one another at the higher nitrogen pentoxide concentrations. The higher analytically determined nitrogen pentoxide concentrations approach to one-half of the expected concentrations, and this was the approximate value given in our previous paper for the fraction which could be determined analytically of a nitrogen pentoxide atmosphere generated from a chloroform solution and brought into contact with experimental animals.

Toxicity.-A summary of the toxicological effects on rats of single exposure to the ozone-nitrogen dioxide atmospheres is given in Table 4. Included in this Table is a column headed "total equivalent ozone concentration". These figures are based on the observation that while the acute toxic action of ozone is similar to that of nitrogen pentoxide, the latter is about three times more active than the former; the measured ozone concentration has been added to three times the measured nitrogen pentoxide concentration to give the total equivalent ozone concentration.

The individual experiments listed in the Table have been arranged in increasing order of total equivalent ozone concentration. The general pattern of symptoms produced by these mixed atmospheres resembled that noted for ozone and for nitrogen pentoxide ; with low concentrations there was mild respiratory distress, with increasing concentrations the rats became rather comatose and as the lethal concentrations were approached acute gasping dyspnoea developed, terminated by death either during exposure or delayed. Histological examination of the lungs of affected animals revealed oedema and emphysema and some congestion of the alveolar capillaries, bur no haemorrhage.

\section{Discussion}

The experimental investigation of the acute toxicity of pure ozone to rats and mice has indicated that the L.C. 50 under our experimental conditions is of the order of 10 to 12 p.p.m. This figure is considerably lower than that arising from Thorp's
(1941) work and agrees with the higher toxicity reported by Witheridge and Yaglou (1939).

The lower safe limit for limited repeated exposures to rats is between 2.5 and 4.5 p.p.m. Stokinger (1954) quotes a much lower figure from McDonnell's work, but this investigator used guinea-pigs and the experiments lasted far longer and the mortalities recorded were due to the development of pneumonia. In our experiment at 4.5 p.p.m. ozone, the one death was probably due to pneumonic infection and it may well be that the chronic toxicity of ozone derives in large part from an increased susceptibility to lung infection.

The general pattern of symptoms and the changes in pulmonary tissue produced by ozone are very similar to those previously reported for nitrogen pentoxide. The L.C. 50 values of the two substances are of the order of 10 to 12 p.p.m. and 3 to 4 p.p.m., which indicates that nitrogen pentoxide has about three times the acute toxicity of ozone.

The analytical figures on the atmospheres containing both ozone and nitrogen dioxide leave no doubt that the two components react in part to form nitrogen pentoxide; there is an approximate equivalence between the loss of ozone and twice the loss of nitrogen dioxide and this figure is of the same order as the production of nitrogen pentoxide when the known loss of this substance under the experimental conditions is taken into consideration. These observations are in accord with the chemical reaction $2 \mathrm{NO}_{2}+\mathrm{O}_{3}=\mathrm{N}_{2} \mathrm{O}_{5}+\mathrm{O}_{2}$. The analytical results are not sufficiently precise or extensive to permit a calculation of the rate and equilibrium constants of the reaction, but it appears that the production of nitrogen pentoxide is a function of the initial concentrations of both components.

The effects produced by exposing rats to atmosphere containing both ozone and nitrogen dioxide demonstrate clearly that the toxicity of the mixture is greater than would be anticipated from the toxicity of the components. This apparent synergism can be satisfactorily attributed to the reaction producing nitrogen pentoxide, whose physiological action is very similar to that of ozone, and the effects of the two appear quantitatively to be additive. If to the measured ozone concentration is added three times the nitrogen pentoxide concentration to give a " total equivalent ozone concentration", the L.C. 50 calculated on this basis is of the same order as that for ozone alone, and for a given total equivalent ozone concentration the toxicity is largely irrespective of whether ozone or nitrogen pentoxide is the major toxic component.

Our experiments have demonstrated that although the toxicity of an ozone atmaspipipan be increased

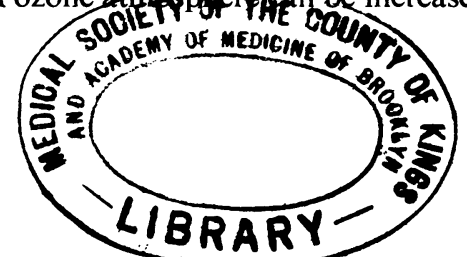


by the presence of oxides of nitrogen, this effect is not significant until the nitrogen oxide concentration approaches that of ozone, when the components are brought into contact at room temperature. We have confirmed in other experiments the observations of other investigators by showing that the usual pattern of ozonizer, operating by a silent electrical discharge on fairly dry air, produces only a negligible trace of nitrogen oxides and therefore nitrogen pentoxide plays no part in the toxicity of an atmosphere so produced. Thorp (1941), however, using a spark discharge, has maintained that he has achieved a mixture in which the nitrogen oxides are present in nearly the same concentration as ozone. It would be interesting and profitable to investigate the nitrogen pentoxide production under such conditions; we ourselves have had the opportunity of making analytical measurements in an insulator testing establishment where there was an evident evolution of ozone in the vicinity of a brush electrical discharge. We have found that an ozone concentration of 2.2 p.p.m. is accompanied by a nitrogen pentoxide concentration of 0.25 p.p.m. These figures indicate that in this atmosphere ozone is the chief toxic hazard, yet the concentration of nitrogen pentoxide, equivalent to 0.75 p.p.m. ozone, is not to be neglected. The nitrogen dioxide concentration was found to be of the order of 1 p.p.m. and did not contribute to the toxicity.

The concentration of ozone which has been recommended by the American Conference of Governmental Industrial Hygienists (1954), not to be exceeded in a factory where men are continually exposed, is $0 \cdot 1$ p.p.m. and the present investigation suggests that it is not unreasonable. We have shown that the assessment of the hazard of an ozone atmosphere by means of ozone determination would be adequate if the ozonization derived from a silent electrical discharge, but it might be misleading when atmospheres produced by spark discharge or other methods are involved.

\section{Summary}

The concentration of ozone which causes $50 \%$ mortality to rats and mice exposed for one period of four hours has been found to be in the region of 10 to 12 p.p.m. The cause of death is acute pulmonary oedema.

A limited number of repeated four-hour exposures on rats at 4.5 p.p.m. causes respiratory distress and the death of one rat, probably due to pneumonic infection. Repeated exposures at 2.5 p.p.m. have no effect.

Dilute mixtures of ozone and nitrogen dioxide in air react in part to give nitrogen pentoxide, the amount produced depending on the concentrations of the reactants. The toxic effects of ozone and nitrogen pentoxide are qualitatively similar, though the latter is about three times as active as the former. The effects are additive and the observed increase in the toxicity of an ozone atmosphere brought about by the presence of oxides of nitrogen can be adequately attributed to the nitrogen pentoxide present.

The effect of these observations on the assessment of the toxic hazard from industrial ozone concentrations is discussed.

We wish to express our indebtedness to Dr. M. W. Goldblatt for advice and to Mr. J. Crozier for technical assistance.

\section{REFERENCES}

American Conference of Governmental Industrial Hygienists (1954) Arch. industr. Hyg., 9, 530.

Diggle, W. M., and Gage, J.'C. (1954). British Journal of Industrial Medicine, 11, 140.

Medicine, 11, 140. Intrum. 29, 409.

Gluckauf, E., Heal, H. G., Martin, G. R., and Paneth, F. A. (1944), J. chem. Soc., p. 1 .

Patty, F. A., and Petty, G. M. (1943). J. industr. Hyg., 25, 361.

Stokinger, H. E. (1954). Arch. industr. Hyg., 9, 366.

Thorp, C. E. (1941), Amer. chem. Soc. (News Edn.), 19, 686.

Wilska, S. (1951). Acta chem. scand., 5, 1359.

Witheridge, W. N., and Yaglou, C. P. (1939). Trans. Amer. Soc. Heat. Vent. Engrs., 45, 509. 